\title{
CHRONICLES OF CIVIL SOCIETY IN ASSAM AND MEGHALAYA: CONVERTING GIRLS AND WOMEN FROM «BAD TO GOOD»
}

\section{Barnali Das}

\section{Rekha Pande}

\section{Abstract}

This paper examines the standpoints and the approach of the stakeholders working towards combatting sex trafficking in Assam and Meghalaya, India, with the aim of understanding whether the selected stakeholders uphold a gender-sensitive conceptualization, understanding and approach towards sex trafficking. Such an approach is significant since it ensures that victims of sex trafficking are protected from further marginalization and exploitation. In contemplating the voices of the stakeholders, the paper shows that the implementation and execution of the anti-trafficking provisions are genderladen. It claims that, while putting the anti-trafficking provisions of prevention, rescue, rehabilitation and repatriation into action, the stakeholders do not differentiate between voluntary and forced sex work. The absence of this distinction results in the "forced rescue" of voluntary sex workers. This article therefore shows how stakeholders impose the idea of "normal womanhood" and constantly seek to control and regulate women's sexuality.

Keywords: Sex trafficking, forced rescue, rehabilitation of victims, gender-sensitive approach.

\section{Resumo}

Crónicas da sociedade civil em Assam e Meghalaya: a conversão de meninas e mulheres de «más em boas»

Neste artigo examina-se os pontos de vista e a abordagem dos/as intervenientes no combate ao tráfico sexual em Assam e Meghalaya, Índia, com o objetivo de entender se os/as intervenientes selecionados/as sustentam uma conceptualização e abordagem sensível ao género relativamente ao tráfico sexual. Tal abordagem é relevante, pois garante que

* $\quad$ Centre for Women's Studies, Dibrugarh University, Dibrugarh, Assam, India.

Postal address: Centre for Women's Studies, Dibrugarh University, Dibrugarh: 786004, Assam, India.

Electronic address: dasbarnali.ghy@gmail.com

** Centre for Women's Studies, University of Hyderabad, Hyderabad: 500046, Telangana, India. Postal address: Centre for Women's Studies, University of Hyderabad, Hyderabad: 500046, Telangana, India.

Electronic address: panderekha@gmail.com 
as vítimas de tráfico sexual sejam protegidas de novas marginalizações e de exploração. Ao analisar as vozes dos/as intervenientes, o texto mostra que a implementação e a execução das disposições anti-tráfico se baseiam numa perspectiva enviesada de género. Defende-se que, embora ponham em prática as disposições anti-tráfico de prevenção, resgate, reabilitação e repatriação, os/as intervenientes não diferenciam entre trabalho sexual voluntário e forçado. A ausência desta distinção resulta no «resgate forçado» de trabalhadoras do sexo voluntárias. Assim, este artigo mostra como os/as intervenientes impõem a ideia de «feminilidade normal» e procuram constantemente controlar e regular a sexualidade das mulheres.

Palavras-chave: Tráfico sexual, resgate forçado, reabilitação de vítimas, abordagem sensível ao género.

\section{Resumen \\ Crónicas de la sociedad civil en Assam y Meghalaya: conversión de niñas y mujeres de «malas a buenas»}

En este artículo se examina los puntos de vista y el enfoque de los/las intervinientes en la lucha contra la trata sexual en Assam y Meghalaya, India, con el objetivo de comprender si los/las intervinientes seleccionados/as defienden una conceptualización, comprensión y enfoque sensibles al género hacia la trata sexual. Este enfoque es importante, ya que garantiza que las víctimas de la trata sexual estén protegidas de una mayor marginación y explotación. Al analizar las voces de los/lasintervinientes, el texto muestra que la implementación y ejecución de las disposiciones contra la trata de personas se basan en una perspectiva sesgada de género. Se defiende que, al poner en práctica las disposiciones contra la trata de prevención, rescate, rehabilitación y repatriación, los/as intervinientes no distinguen entre trabajo sexual voluntario y forzado. La ausencia de esta distinción da como resultado un «rescate forzoso» de trabajadoras sexuales voluntarias. Por lo tanto, este artículo muestra cómo los/las intervinientes imponen la idea de «feminidad normal» y intentan constantemente controlar y regular la sexualidad de las mujeres.

Palabras clave: Trata sexual, rescate forzoso, rehabilitación de víctimas, enfoque sensible al género.

\section{Introduction}

Sex trafficking is one of the serious human rights violations and a form of gender-based violence. Victims of trafficking lose their right to freedom and life, and are violated physically, sexually and psychologically. The strategies and methods to address this problem have been multifarious. The national and international responses have created a range of methods to deal with the phenomenon. However, despite the robust national and international measures, there remains considerable uncertainty and debate over the gendered implementation of these measures. To establish the argument the following gives a brief summary of the international and national measures on human trafficking.

The history of international responses to sex trafficking dates back to the $19^{\text {th }}$ and $20^{\text {th }}$ centuries. After a multitude of changes, the first international protocol for 
human trafficking was accepted in the year 2000. The history of anti-trafficking measures in India began with the surveillance of "Indian Prostitutes" in the 1870s and 1880s, with the introduction of the Contagious Diseases Acts (Tambe 2009, 52). The beginning of the anti-trafficking era in India deemed trafficking of women from other parts of the country as less important and showed more concern over the trafficking of women from Europe (Tambe 2009, 123). Sex trafficking was formally defined as a crime in 1860, when the Indian Penal Code criminalized acts that involved buying, selling or kidnapping of children for prostitution and violation of their rights (Tambe 2009, 28).

However, the formal fight against sex trafficking in India commenced in 1956 with the Suppression of Immoral Traffic in Women and Girls Act. This law adopted an abolitionist stance, and to redress sex trafficking it targeted sex workers, brothel owners, pimps and customers. Nonetheless, in 1986 The Immoral Traffic (Prevention) Act with minor changes amended the previous act. Unlike the Suppression of Immoral Traffic Prevention Act, it did not criminalise the sex workers. However, it targeted the customers of sex workers, and this provision of the act is vehemently opposed by the sex workers collectives in the country.

Moreover, apart from the Immoral Traffic (Prevention) Act of 1986, India had drafted and implemented other acts which address the problem of trafficking in persons: the Prohibition of Child Marriage Act (2006), the Bonded Labour System (Abolition) Act (1976), the Child Labour (Prohibition and Regulation) Act (1986), and the Transplantation of Human Organs Act (1994). Further, India has also designed the Ujjawala scheme to specifically address the problem of trafficking in girls and women. The components of this scheme are a) prevention, b) rescue, c) rehabilitation, $d$ ) reintegration and e) repatriation of trafficked victims.

Given the above context of anti-trafficking measures, this paper argues that the measures lack a gender sensitive approach towards sex trafficking. It argues that such an approach is a necessary a priori condition to deal with the phenomenon as well as the victims of sex trafficking. Such an approach would aid in the mental and physical well being of the victims. Cunha $(2002,4)$ posits a revisit of the discourse and interventions of sex trafficking, and asserts that a gender sensitive orientation is central to the anti-trafficking strategies. Such an orientation would necessitate a multi-sectoral and a gender-sensitive approach to prevention, protection and assistance. Cunha $(2002,8)$ argues that the susceptibility of women and girls as victims of sex trafficking is grounded in their «marginalized social locations». «Measures that reproduce gender stereotypes, reinforce discrimination and control over women should be challenged» (Cunha 2002, 13). However, the implementations of the national and international interventions on human and sex trafficking lack the concerns of gender stereotypes and necessarily reinforce discrimination and control over women. The subsequent sections of this paper prove the lack of gender sensitivity amongst the stakeholders of sex trafficking. 
This context of gender sensitivity is put forth by a report developed by ASEAN $(2016,11)$, which stresses the need for a gender-sensitive anti-trafficking approach. Further, a training guide designed by the Organisation of American States $(2010,7)$ argues for a gender sensitive and strategic planning which recognises disparities and discriminations, and outlines necessary actions and activities that satisfy the "practical as well as strategic needs of women». This paper joins this debate on a gender-sensitive approach to address the phenomenon as well as the recipients of the phenomenon. A gender-analysis approach is adopted, based on the claim that, although there is a robust body of anti-trafficking measures, the implementation of these provisions are found to be gender-laden. It argues that the stakeholders implementing the anti-trafficking provisions of prevention, rescue, rehabilitation and repatriation fail to distinguish between voluntary and forced sex work. The absence of this distinction results in the "forced rescue" of voluntary sex workers.

Further, the ideological framework of the stakeholders is found to have moralistic stand points on sex trafficking, which leads to the categorization of trafficked women as "bad" and "immoral" women. The narratives included in this paper indicate that these ideologies are guided by strong notions of permitted sexuality, which is legitimate heterosexuality, and since victims of sex trafficking are outside of this framework, we find a continuous effort to "mainstream" them into the category of "normal asexual women".

This paper argues that the rationale behind the moralistic stance on sex trafficking is based on a gendered construction of sexuality that imposes an «inferior sexual identity» on women (Chow 2003, 97). The voices cited in this paper show how the stakeholders impose the idea of "normal womanhood" and constantly seek to control and regulate women's sexuality (Chow 2003, 100). The empirical accounts included here reveal that stakeholders vehemently oppose sex work and, in the guise of addressing sex trafficking, seek to eradicate and disrupt sex markets. This attempt is understood as a necessary condition to wipe away the phenomenon of sex trafficking.

The first part of the paper presents the methodology that we adopted in the field work of the study, while the second part provides a feminist framework on sex trafficking, which explores the abolitionist and regulationist school of thought, and the third part discusses and provides gender analyses of the chronicles of the civil society.

\section{Research}

The complexities involved in the epistemology of sex trafficking demand an intensive study of sex trafficking. Owing to the sparse research on the phenomenon in Northeast India, this study is based in the regions of Assam and Meghalaya 
(India). The districts selected for Assam include Kamrup, Baksa, Sonitpur, Nalbari, Namrup, Sivasagar, Tinsukia and Dibrugarh, while those of Meghalaya include East Jaintia Hills, West Jaintia Hills, East Khasi Hills and West Khasi Hills. The states are located in the northeastern region of India and cover a total area of 78,438 sq. kilometers (Assam) and 22,429 sq. kilometers (Meghalaya) respectively. Due to their poor economic backgrounds, the states lay a fertile ground for the crime of sex trafficking.

Although women in both states are bound by different social systems, wherein Assam is a patrilineal and a patrilocal state and Meghalaya is a matrilineal and matrilocal state, the status of women in both states is inferior, subordinate, and secondary to that of their counterparts. These states function under multiple patriarchies that create disparate socio-economic and political situations of subordination for women. This therefore has its effect on the growing incidences of trafficking for commercial sexual exploitation.

To encapsulate the multiple voices within civil society, this research study collected information from a total number of 37 respondents, 19 of which were from non-governmental organizations. The study also found that in Meghalaya the Church plays a pivotal role in the socio-economic construct of the state and in spreading awareness against sex trafficking. Therefore, to situate and understand the phenomenon of sex trafficking in Meghalaya the study took responses from 10 Pastors from the Synod and Presbyterian Church. In addition to this, the researcher found that the church in Meghalaya has drop-in centres, which counsel sex workers. Further, the researcher interviewed 5 headmen of the village council (Dorbar) in order to get a nuanced perspective on sex trafficking in the state. The researcher also interviewed three politicians in Assam and Meghalaya respectively. This enabled the researcher to receive an understanding of the state's approach to sex trafficking. Considering the sensitivity of the topic, pseudo names for the respondents have been used and the names of the organizations have been kept anonymous.

In order to conduct the present study, the researcher used feminist standpoint theory. The foundation of this study was based both on primary and secondary sources. For primary data collection, the researcher made several visits to the offices of NGOs and police stations located in Assam and Meghalaya. Since the church plays an important role, the researcher visited the Synod and Presbyterian Church of Meghalaya, in order to get wider perspectives of the stakeholders involved in the drive against human and sex trafficking.

This study is based on criterion, convenience and snowball sampling method. It is built on a narrative phenomenological approach and case study approach (Adu 2016). The philosophical paradigm is based on "social constructivism" (Adu 2016). The ontology of this paradigm is based on realities that are created through individual interactions. 


\section{Feminist Debates on Sex Trafficking}

The concept of consent/non-consent has been the central parameter of the debates and arguments between two feminist schools of thought: the abolitionists and the regulationists. The former negate all forms of consent involved in sex work, while the latter demand to consider the consent of voluntary sex workers as an efficient way to address the problem of sex trafficking. In alliance with conservatives and evangelical Christians, the school of abolitionism has used the anti-trafficking movement as a means to abolish prostitution (Chuang 2006, 1658). An understanding of these two schools of thought is paramount to contemplate the ideological locations of the stakeholders of the research.

The abolitionist schools of thought make no distinction between forced and voluntary prostitution. Both forms of prostitution are considered to be coerced, since they conceive of prostitution as an institution of male dominance which is devoid of meaningful choice and consent (Chuang 2006, 1664). Abolitionists aim to remove prostitution from public sight (Tambe 2009, 101), and therefore have a reductionist approach to trafficking.

The early first and second-wave feminists were in alliance with the social purity campaigners, and as such their main concern was to protect "fallen women" from the vice of prostitution. Radical feminists and polemicists such as Kathleen Barry articulated prostitution as an inherent assault on the dignity of women and saw it as a product of men's sexual violence that had taken a vicious form in the shape of human trafficking (Weeks 2011, 139).

The Indian women's movement against sex trafficking did not depart from the abolitionist ideology, the impact of which led to the abolition of the Devadasi system or temple dancing girls (Tambe 2009, 104). It rose with the demand of the middle-class women's movement to abolish the system of Devadasis as they conceived it to be a form of prostitution. They reasoned it was based on temple dancers being engaged in offering sexual services to male patrons and prohibited from getting married (Tambe 2009, 104). Therefore, early women's associations, such as the Women's India Association (WIA) of 1917, the All India Women's Conference (AIWC) of 1926, and the National Council of Women in India (NCWI) of 1925, promoted legislation against the Devadasi system (Tambe 2009, 104). The WIA journal Stri Dharma regularly published against the Devadasi system, often associating it to prostitution (as cited in Tambe 2009, 104). The Women's Movement led legislation against the Devadasi system, which resulted in the denial of Devadasis' claims to temple property as well as inheritance rights. The first strike on the Devadasi system was due to the Devadasis resisting marriages (Tambe 2009, 105).

Therefore, the Indian women's movement and the nationalists had a paradoxical approach to prostitution. On the one hand, they pitied the prostitutes for having been robbed of their chastity and honour, and on the other hand they con- 
sidered them to the thieves of the moral purity of society. This led the early Indian women's movement to have a wider abolitionist approach (Tambe 2009, 107). The narratives included in this paper demonstrate an abolitionist stance, thereby blurring all distinction between forced and voluntary sex work.

However, the abolitionist struggle of the radical women's movement has been challenged by the postmodernist feminists, who have critiqued the modernist explanation of dominance and victimisation (Lansink 2006, 51). The defenders of sexual rights see a sharp distinction between children forced into prostitution and women who make a choice to enter the sex trade (Weeks 2011, 216). «They embrace what Sandra Harding has called "the fractured identities of modern life" and emphasise the local and the specific context of women's real life experiences (Harding in Charlesworth and Chinkin, 2000: 44)» (as cited in Lansink 2006, 51). Therefore, the postmodern, liberal and libertarian feminists have emphasised choice, agency, and freedom to choose work (Lansink 2006, 51).

The regulationist or the liberal feminist political model of sex work recognises the autonomy to engage in sexual labour. It critiques the abolitionist school of thought and states that «conflating trafficking and prostitution would divert attention from combating trafficking effectively» (Lansink 2006, 51). It counters the discourse that brings voluntary sex work into the scope of trafficking and impacts on the development of anti-trafficking measures. It argues that it negatively impacts the possibility of effective strategies, as resources would be diverted to combating prostitution rather than the very serious crime of trafficking. Within the context of trafficking, prostitution is always unacceptable, because it is done under coercive circumstances for the purposes of exploitation. But this should be separated from including all (adult) consensual recruitment or migration for sex work as trafficking (Lansink 2006, 52). Therefore, according to the regulationist school of thought, coercion is an indispensable element of sex trafficking (Doezema 2002, 20). It places women's sexual autonomy at the centre and argues that negating the dynamics of consensual sex work is anti-feminist and a threat to women's sexual autonomy (Doezema 2002, 21).

Within this framework, the Indian collectives of the National Network of Sex Workers, the Durbar Mahila Samanwaya Committee and the Veshya Anyay Mukti Parishad (VAMP) demanded to license sex work. They argue that the licensing of sex workers would not only guarantee their rights, but also enable the state to address the problem of sex trafficking. In this context, this paper critiques the gender-laden approaches of stakeholders and maintains that the effective strategy to deal with the phenomenon of sex trafficking is a gender-sensitive approach and the recognition of the distinction between forced and voluntary sex work. 


\section{Multiple Voices}

This section seeks to analyze the various aspects of sex trafficking. Delving into pre-rescue exploitations, standpoints on rescue, rehabilitation, approaches to redress sex trafficking, converting from "bad to good" girls and women and conditions of retrafficking, it examines the narratives and standpoints of the civil society. Within the framework of gender sensitivity, the subsequent section examines the said approaches.

\section{Pre Rescue: Breaking-in}

Regarding the process of breaking-in victims into the commercial sex trade, the narratives from the civil society unanimously mentioned instances of extreme physical and mental violence. Mary's experience of working with victims of sex trafficking reveals the following:

Victims of sex trafficking undergo immense mental tortures. They blackmail the victims by saying that «if you don't do as we say, we are going to harm your family». These are forms of emotional blackmail. Trafficked victims are also kept in isolation for days. (Mary, NGO worker, Meghalaya, 16 July 2016)

Placing experiences at the centre, this paper finds that emotional blackmail is one of the methods to exploit the vulnerability of trafficked victims. The realities of breaking-in experiences of violence show that traffickers exert physical and psychological tortures. Also, to silence and torture them, traffickers threaten to kill their families. These experiences of breaking-in create the epistemology of exploitation inflicted upon victims of trafficking.

\section{Rescue}

Rescue is found to be one of the primary anti-trafficking drives of the stakeholders. The foundation upon which the idea of rescue is based is to save and retrieve girls and women from situations of forced sex work and extreme exploitation of the pre-rescue phase (Sen and Nair 2005). The underlying principle of rescue is rescue from pre-rescue exploitation and "forced sex work". Nonetheless, the firsthand accounts of stakeholders have revealed a reversed understanding of this principle. We found that stakeholders have a falsified sense of the idea of rescue. An analysis of these standpoints found that stakeholders failed to distinguish between forced and voluntary sex workers, which has led to the "forced rescue" of sex workers who are willingly engaged in the business of commercial sex.

The following extract is an example of this falsified understanding of rescue, conveying the idea that rescue is a drive against the sex markets. 
Rescue operations involve stake and risk. We cross check the information we receive. We go to the place and find out how far the report is true and ask nearby shops and neighbours. Further, we observe the house about which we had received information of "bad" activities. We have our informers who report to us about the cases. (Manjula, Assam, NGO Worker, 1 March 2016)

Another narrative reveals how the parameter of "age" acts negatively for an adult woman who had voluntarily worked in the business.

One of the major challenges today is the definition of human trafficking and prostitution. There exists a thin line between both phenomena. Right to consent is not given to an individual below 18 years. Our organization adopts the age of consent as fixed by the United Nations. Thereby, while conducting rescue of trafficked victims the age at which the victim was trafficked is taken into account. A victim might state that she is fine with the work then. However, when the incident happened, it happened when she was a child. We take that age and fight against child and women trafficking. If a sex worker above the age of 18 says «I am doing it willingly», then the personal rights of the women becomes an important aspect of consideration. Although India has not legalized prostitution, it is about choice, personal rights and women's rights. However, many organizations while conducting raids pull out willful sex workers and present them as victims of trafficking. (Heena, NGO Worker, Meghalaya, 7 July 2016)

This reflects the complicated dimension of the phenomenon and the drives against it. The respondent refers to a willful sex worker who was initially trafficked but later consented to work. Therefore, the voices at the centre of this paper bring to light the gendered construction of sexuality that leads to sublimate, ignore and silence sex workers.

Based on the standpoints of the stakeholders, we argue that the trafficked victims' consent is never taken into account in the process of rescue. Due to the controlled and regulated sexuality of women, the excerpt here clearly reveals that the consent of willful sex workers is never considered. A similar standpoint of forced rescue is elucidated below:

The woman about whom I spoke was there in the red-light area and so we rescued her. Although the woman settled into the profession of sex trade, however she was originally a trafficked victim... (Rita, NGO Worker, Meghalaya, 16 July 2016)

In this narrative the respondent admits that voluntary sex workers are forcefully rescued from the business that they are settled in. Through a feminist analysis of this standpoint, we argue that forceful rescue is a displacement of women and their work, which results in depression, distress, emotional and economic turmoil. A respondent said the following: 
In one of the recent cases the victim who we have rescued also has an old shop in that particular place. They have their family. They have a shop. Everything is there and she told us that she is not into that trade anymore. We have found that many of them are not willing to be rescued. (Tiloka, NGO Worker, Assam, 7 March 2016)

The narrative throws light on the forced rescue and extraction of sex workers. Through the lenses of women's experiences of violence, this data shows the extraction and economic displacement of empowered women. Such kind of rescue pushes women to disadvantageous positions and puts them in economically distressed situations. This reveals a falsified understanding of rescue and sex trafficking. The respondent clearly shows evidence of her non-comprehension of the phenomenon, and this has led to the economic displacement of the woman.

\section{Shelter Homes}

The rescued trafficked women and girls are rehabilitated in shelter homes that are ty pically designed to provide protection and necessary services. However, the data collected for this study shows it to be an uncomfortable space for victims. The respondents from the civil society point out the amount of insufficient and non-nutritious food provided to the victims who are being caged in the shelter homes. Based on the experience of working in rescue homes, one of the respondents discloses the mental ostracization that rescued victims of trafficking undergo (Noor, Social Worker, Assam, 19 October 2017).

Is it important to know her entire story and insult her for the mistakes she had made in the past? Or is it important to provide solace and shelter to her? This is the reason why they have a negative mind. They [staff] would repeatedly reiterate that she was a bar dancer... (Noor, Social Worker, Assam, 19 October 2017)

Though the respondent's patriarchal mindset could be seen, yet a compassionate approach is found in Noor's articulation of the shelter home. Her views are patriarchal because she considers sex work, voluntary or forced, as the mistake of girls or women. The consequence of this "mistake" is social ostracization and the labelling of women as "bad" and "evil". These articulations of "bad" and "evil" are in line with the learned perceptions of sexuality which are imposed on social actors. Any deviation found or committed means necessarily to be outside the parameters of a normal and good woman.

Further, on account of disobedience and non-adherence to rules, there are cases wherein victims are thrown out of the shelter home. One of the respondents said the following: 
Recently a mentally unstable girl was admitted in our shelter home. However, before our arrival she was sent back to her home. I told the other staff that they had not done a wise thing. The girl was mentally unstable. (Noor, Social Worker, Assam, 19 October 2017)

The study also found that a trafficked victim was sent back to Silchar, her place of origin, without being accompanied by an NGO staff member. She was sent back because she was creating a problem in the home and was unmanageable by the staff. In one of the instances, the girl tried to undress and show herself to a passerby. Therefore, the staff decided to get rid of her.

According to the voices in this study, shelter homes are spaces wherein inmates are incarcerated. The rationale behind this incarceration is "safety" and "protection" of trafficked girls and women. However, from a feminist standpoint and epistemology, one can argue that this process of arbitrary incarceration as a mechanism of protection is based on the ideals of patriarchal control and repression of women. Referring to this phenomenon of incarceration, one of the respondents spoke about the inmates' desire for freedom. He said that «being locked in the shelter home they feel suffocated from within. The only desire they are left with is their freedom and they are desperate about it» (Kamal, Assam, 7 March 2016). During the interviews, the respondents spoke about victims being locked in the shelter homes. Referring to this, one of the respondents said:

This is because of the fact that by jailing women in the shelter homes one is trying to disempower a woman. They remain aggressive within these spaces. They run away. A number of these shelter homes sometimes focus on the numbers of victims that are been put into these homes and that they do not reintegrate them. (Josephina, NGO Worker, Meghalaya, 27 July 2016)

The conditions of the shelter homes are disclosed to be extremely inadequate, and victims reside in what can be described as regulated and surveillance sites.

In India shelter homes are in pathetic conditions. In a single room five inmates are accommodated. Victims are provided undernourished food in the shelter homes. Most shelter homes just provide dal, rice and potato. They have no lifestyle within the shelter homes. (Kamal, NGO Worker, Assam, 7 March 2016)

The desire for freedom is curtailed in the shelter or rescue homes. The responses underline that the shelter homes are spaces of discipline and control, which create a sense of suffocation and make it more of an incarcerated site. This shows a patriarchal model of rehabilitation where the disciplining of "non-docile" bodies is primary, while the victims' desires and voices are secondary and essentially subdued and ignored. 
The inmates wish to go to back to their native places. However, due to official formalities, it is deterred by the in-charge of the rescue home. Further, victims often complain of feelings of suffocation. This is because they are locked and jailed in shelter homes. Thereby, the desire that victims repeatedly express is of freedom and they are desperate about it. (Noor, Social Worker, Assam, 19 October 2017)

Mary, an NGO worker, confirms this situation:

Victims of sex trafficking are kept captive in the shelter homes, toward which they have a great deal of discontentment. This is because they feel that they are curtailing their freedom. They think that they have come to another jail. There are rules that one has to follow. (Mary, NGO Worker, Meghalaya, 16 July 2016)

The standpoint of the respondents reveals that the shelter homes are spaces to discipline and regulate women's bodies. A critical feminist analysis of these standpoints shows that these spaces constantly seek to "mainstream" trafficked women. It is found to be a site with strict rules and regulations to control the victims who have deviated from the category of "good women". The restrictive nature of these sites is revealed through the respondents' statements about the fact that victims run away from these rehabilitation spaces.

\section{Redressing Sex Trafficking}

The above attempts to redress sex trafficking show that, in Assam and Meghalaya, raids, rescue and rehabilitation are considered as important mechanisms or elements of anti-trafficking. In doing so, the data finds that curbing the sex trade is an evident attempt made by the civil society. In response to sex trafficking, a respondent said:

We feel that, when it comes to legalising prostitution, what happens is that this industry would boom rather than be curbed. Legalisation would encourage traffickers to bring in girls. Legalisation would set an easy stage for traffickers. (Bhatta, Politician, Assam, 5 October 2017)

Thereby, since sex trafficking could be articulated within the paradigm of women's sexuality, the efforts of society are towards the control, regulation and repression of women's sexuality. In this context, the above excerpt leads us to problematize the efforts of the civil society and to argue that, under the guise of curbing sex trafficking, the efforts are to curb voluntary sex work. This context is further put forth by Jameela $(2018,17-18)$ who argues that, while the Indian legal system does not per se consider sex work as an illegal activity, yet the police and the legal system persecute sex workers. 
Within this framework of restricted women's sexuality, another respondent victoriously spoke about her success in wiping away sex markets. Further, the study found that, in Meghalaya, an attempt is made to curb the entry of outsiders into the state. Concerning this a respondent said:

When our union became aware about sex trafficking, we set up a board to address the problem of sex trafficking in Meghalaya. We have awareness programmes. We don't allow the non-tribal people to come into our areas. We do so with the help of Dorbars (village council). We have this concern because we are aware that human trafficking and sex trafficking are occurring in Meghalaya and hence to avoid it, we have developed this mechanism. (Rahul, President Student's Union, Meghalaya, 11 July 2016)

This member of the civil society argues that an abolitionist stance with no distinction between forced and voluntary sex work could be an effective method to address and redress the phenomenon of sex trafficking. He also alludes to the presence of outsiders in Meghalaya, and to prevent sex trafficking in the state he urges the restricted entry of outsiders.

This study argues that the moral stance held by the abolitionists as an approach to redress sex trafficking could be critiqued and questioned (Doezema 2002; Sharma 2005; Cavalieri 2011). The method to disrupt and dismantle sex markets in order to control sex trafficking is argued to be a patriarchal and a statist approach to redress sex trafficking. It is based on the sexuality of women which has been constructed as an inferior, controlled and highly surveilled site of society, therefore any puncture on it causes increased moral and social imbalances in the social milieu.

\section{Converting Girls and Women from Bad to Good}

The efforts to redress sex trafficking by the members of the civil society reveals the necessity to bring trafficked victims into the "mainstream" society. They often mentioned that girls who become habituated to sex work are difficult to pull back to the normal course of life. The only way to deal with this problem is to provide counselling to rescued trafficked victims. Referring to this, one of the respondents said:

Their sexual needs are higher than that of normal people. To counsel them and bring them back to the mainstream is difficult. We have to have patience when dealing with them. (Jyoti, NGO Worker, Assam, 25 November 2016)

This stance of "mainstreaming" victims from "bad to good" girls and women is mirrored in the narrative of the majority of respondents. The narratives reflect the framework of the socially acceptable category of good women who are essen- 
tially chaste and sexually untouched and non-violated. The research found that the narratives were strictly restricted within this category of good versus bad women. This category of bad women is problematized by Jameela $(2018,13)$, who argues that a bad woman is one who ventures and travels at odd hours and one who does not follow the regime of the strict heterosexual order. To repress and regulate these categories of "bad women", the emphasis has increasingly been laid on combating sex trafficking as an immoral and non-ethical crime.

Nonetheless, some of the respondents also acknowledged that victims need counseling to recover from the physical and mental violence that they had undergone. Noor said:

According to me, counselling is the main treatment for rescued trafficked victims. With the help of love and care one can make a victim comfortable and secured to speak and tell their stories. This exercise helps them immensely to release their emotions and frustrations. Thereby, since counselling provides mental support, the recovery of victims becomes easier. (Noor, Social Worker, Assam, 19 October 2017)

However, most of the respondents mentioned that counselling was a technique to "mainstream" trafficked girls and women. They stated that being a trafficked victim means that they are lost, and it is imperative to bring them back to the normal life. The following narratives are about this aspect of mainstreaming trafficked victims:

See, trafficked girls are different from any other girls. When it comes to counselling them, they behave differently. Their physical need is higher than that of normal people. They are used to it. They do not trust people easily. Anyone who comes to them, they think of them as their client. So, to break that is difficult...

I believe there is another breaking-in phase. However, the process of breaking in the victims in pre and post rescue is discrete. In post-rescue there is counselling and rehabilitation. We have the work for reintegrating the victims into the society. (Mary, NGO Worker, Meghalaya, 16 July 2016)

In the discourse of sex trafficking breaking-in means physical and psychological violence used to coerce victims into the sex trade. The use of this term in the post-rescue situation reflects the respondent's approach of force and coercion to bring victims into the "normal life".

These narratives throw light upon the argument of this research study, which is that stakeholders seek to mainstream trafficked girls and women. Mary argues that the sexual need of trafficked women is higher than that of "normal women". The category of "normal women" in this context is one who is "asexual, chaste and pure". It is also implied that "normal women" do not reveal their sexual urges and 
desires. Mary's narrative shows her comparison of this internalized category of "good and normal women' vis-à-vis "bad and abnormal women". A similar standpoint is reflected in Rita's narrative: "A rescued trafficked victim after being brought to a shelter home is required to receive counselling, so that it helps the victim to recover and come to the mainstream life» (Rita, NGO Worker, Meghalaya, 16 July 2016).

\section{Re-trafficking}

Forceful rescue, confinement in rescue homes, and the gendered attempts to mainstream rescued trafficked girls and women result in creating conditions of re-trafficking. In this context, the narratives show that one of the primary causes of re-trafficking is the assurance of providing a comfortable life to the victims. In this respect, one respondent reflects that «If one is enjoying a luxurious car, then why would one wish to board an auto-rickshaw? Therefore, in the hope of comfort, luxury and money, the girls get retrafficked» (Rima, NGO Worker, Assam, 12 July 2016). Another respondent said the following:

Most of the rescued victims of trafficking that I have come across want to go back to the brothels. On the one hand, we want to rescue them from the "wrong direction". On the other hand, they wish to go back to the place. (Sarita, NGO Worker, Assam, 13 July 2016)

According to the findings of this study. the cases of re-trafficking are high. However, one has to look into this context of re-trafficking within the dimensions of choice and consent. This is because the respondents expressed their desire to return to the sex markets. Therefore, the notion of rescued trafficked women and girls as passive victims could be challenged in this context, as they constantly transgress the boundaries of victims and active agents.

As has been discussed, victims of trafficking after rescue are not freed from suppression and domination. They are subjected to innumerable forms of marginalization after rescue. As we stated before, within shelter homes victims are incarcerated, and as a consequence they choose to elope and put themselves in disadvantaged positions that make them susceptible to re-trafficking.

\section{Gender Sensitive or Gender Insensitive Approach?}

In the process of rescue and rehabilitation of trafficked victims, civil society plays a very integral role. In this regard, adopting a gender perspective in their approach is imperative. Thus, this section looks into the approach adopted by civil society organizations and other stakeholders of sex trafficking. 


\section{Gendered Treatment of Trafficked Victims}

The members of civil society subject victims to acute forms of gendered treatment. The narratives in this study show that the approach of civil society is distinct towards trafficked men and women. If a girl or a woman is rescued from bonded labour or from sexual slavery, the members of civil society incarcerate them in shelter homes. However, if a boy or a man is rescued, he is directly re-integrated into society. The reason cited by a respondent is that society is more open towards boys and men and has no problem in accepting them. However, a girl or woman is subjected to deep ostracization by the society, which judges her according to the standards of purity and impurity. In this respect, one respondent said: «Some trafficked victims become habituated to the business of prostitution and it is important for us to counsel them and bring them back to normal life» (Tiloka, NGO Worker, Assam, 7 March 2016). The following narrative is an example of the gendered treatment of trafficked victims:

In 2015, we rescued 52 boys from Bangalore. We rescued them from an agarbati (incence sticks) company. Out of the 52, two were from Arunachal Pradesh, the rest were from Assam. The traffickers said that they would give them jobs in Bangalore. After reaching Bangalore they recruited them for a factory. In the first few months of their recruitment, they sent money to their families. However, later their families stopped receiving money. On further probe, we were told by the boys that their daily wage was Rs. 10/-.

We don't keep boys in shelter homes. After rescue, when they return to Assam, we register their names and sent them back to their homes. We do so in cooperation with the Guwahati Railway Police Station (GRPS), and accordingly book their tickets for their respective homes and sent them back. Further, they go by themselves and we do not escort them. (Tiloka, NGO Worker, Assam, 7 March 2016)

The narrative refers to the gendered understanding of human trafficking and its allied protocols of rescue and rehabilitation. It is implied that, since men and boys are outside the construct of "chastity and purity", they lie outside the gendered practice of rehabilitation and protection. It essentially denotes that only girls and women are rehabilitated and restored into societies. Since in this context the victims were boys, there was no requirement of rehabilitation and protection. Also, the respondent stated that boys are easily welcomed by family and society, while girls suffer abandonment and isolation from family and society. This is disclosed in the following statement:

The boys are more eager to return back home. Their families want them to return home. In this context, the gender differences reflect because when girls stays outside 
and then return back home, they undergo opposition and questioning by their community, village and family. A number of questions arise, such as where they were. Moreover, there is stigma attached to girls. Due to which there is a question of whether the family would accept her or not. If the family is ready to accept her, they are scared of their community.

Shelter homes for boys exist, however there are no shelter homes for men. These shelter homes act like corrective homes for men wherein they are kept under observation if they commit any punishable offence such as rape, murder and so on and so forth. (Tiloka, NGO Worker, Assam, 7 March 2016)

The excerpt shows that the framework of shelter for trafficked victims is typically meant for girls and women who are victims of sex trafficking. According to the respondent, men and boys do not need shelter, but rather corrective homes in case of murder, rape or other kinds of punishable offences committed by them. It could thus be argued that the rehabilitation approach is gendered, because rehabilitation and rescue homes are essentially meant for one particular gender, i.e. women, and typically for one category of human trafficking, i.e. sex trafficking.

\section{Gendered Approach in Awareness Programme on Women and Trafficking}

The element of "prevention" involved in the discourse of anti-trafficking mandates that organizations should adopt adequate awareness programmes to prevent and deter the phenomenon of sex trafficking (UN 2000; MWCD n.d.). These programmes are held to spread awareness and consciousness about the clandestine nature of sex trafficking.

This philosophy of awareness and prevention programmes is found to be gendered and androcentric in nature, representing an attempt to restrain women's mobility and free will.

We begin the awareness programmes by speaking about women being inherently weak in education and economic spheres. Lack of education makes women unaware. They are ignorant about schemes and provisions given by the Government. (Kamal, NGO Worker, Assam, 7 March 2016)

The respondent in this narrative spells out the constructed gendered cause of sex trafficking, which in this context is the constructed and false understanding of the weak bodies of women. His awareness programme is repressive and gendered because it reiterates that women are weak and uneducated, and thereby they become easy targets for traffickers. Such kind of consciousness would deepen the subjugation and marginalization of women. 


\section{Conclusions}

The research study described in this paper confirms the gender-laden approach of the stakeholders involved in combatting sex trafficking. Such an approach fails to adequately address the concerns and needs of rescued trafficked victims. Based on the findings of this study and the experiences of working in the field, it argues that this approach further deteriorates the mental and physical conditions of trafficked girls and women. It places them in situations of self-doubt, anguish and self-loathing.

The gendered approach and fractional understanding of sex trafficking are reflected in the findings of this study. For instance, the falsified notion of rescue as upheld by the stakeholders resulted in the forced rescue of voluntary sex workers. Further, the article argues that coercive rescue places women in precarious positions and places them in economically hazardous situations. These finding suggest that stakeholders have a partial understanding of sex trafficking.

Further, rehabilitation of rescued trafficked victims is found to be based on the ideologies of patriarchy and gendered socialization. The narratives indicate that rescue homes incarcerate women and are a highly surveilled and patriarchal site for women. In addition, the findings suggest that stakeholders fail to offer a constructive rehabilitation of victims, which should provide healthy and gender-sensitive counselling to fight their trauma. The approach to counselling is found to be within the categories of "good and bad" women or based on the idea of "normal womanhood". These categories of "good and bad" women tend to further marginalize rescued trafficked victims.

Therefore, the findings presented in this paper lend support to the argument that, in the name of combatting sex trafficking, stakeholders frequently tend to curb sex work. The paper suggests that the aim of the stakeholders was not to fight against the multiple conditions of servitude involved in human trafficking, and their narratives evidently reflect a gender-biased approach and an over emphasis on sex trafficking. The rationales behind this emphasis are the polarities of morality and immorality, the normative binary of good or bad ascribed to the bodies of women. Thus, the implication is that, for stakeholders, the disruption of sex markets is held as a necessary precondition to deal and uproot the problem of sex trafficking.

\section{References}

Adu, Philip. 2016. «Writing the methodology chapter of a qualitative study.» Available at: https: / / www.youtube.com / watch?v=KRHvxY3N708 [Accessed 24 November 2019]. ASEAN. 2016. Gender Sensitive Guideline for Handling Women Victims of Trafficking in Persons. Jakarta: ASEAN Secretariat. Available at https://asean.org/wp-content/uploads/ 2012/05/FAASN_gender_8_email_REV.pdf [Accessed 15 April 2021]. 
Cavalieri, Shelley. 2011. «Between Victim and Agent: A Third-Way Feminist Account of Trafficking For Sex Work.» Indiana Law Journal 86(4): 1410-1458. Available at https:/ / www.repository.law.indiana.edu/ilj/vol86/iss4/ 5 [Accessed 14 April 2015].

Chow, Rey. 2003. «Sexuality.» In A Concise Companion to Feminist Theory, edited by Mary Eagleton, 93-110. Malden, MA: Blackwell.

Chuang, Janie. 2006. «Beyond a Snapshot: Preventing Human Trafficking in the Global Economy.» Indiana Journal of Global Legal Studies 13(1): 137-163. Available at: https:/ / www.repository.law.indiana.edu/ijgls/vol13/iss1/5 [Accessed 23 August 2012].

Cunha, Jean D. 2002. «Trafficking in Persons: A Gender and Rights Perspective.» Report prepared for the UN Expert Group Meeting on «Trafficking in Women and Girls», 18-22 November, Glen Cove, New York, USA. Available at https: / www.un.org/womenwatch/daw/ egm/trafficking2002/reports / EP-DCunha.PDF [Accessed 15 April 2021].

Doezema, Jo. 2002. «Who gets to choose? Coercion, consent, and the UN Trafficking Protocol.»GenderandDevelopment10(1):20-27.DOI:https: / / doi.org/10.1080 / 13552070215897

Jameela, Nalini. 2018. Romantic Encounters of a Sex Worker. Uttar Pradesh, India: Om Books International.

Lansink, Annette. 2006. «Human Rights Focus on Trafficked Women: An International Law and Feminist Perspective.» Agenda: Empowering Women for Gender Equity 70. Gender-Based Violence Trilogy vol. 1-2: 45-56.

MWCD. n.d. «Ujjawala Comprehensive Scheme for Prevention of Trafficking and Rescue, Rehabilitation and Re-Integration of Victims of Trafficking for Commercial Sexual Exploitation.» Ministry of Women and Child Development, Government of India, New Delhi. Available at https://wcd.nic.in/sites/default/files/Ujjawala\%20 New\%20Scheme.pdf [Accessed 6 September 2011].

Organization of American States. 2010. Training Guide. Participatory Strategic Planning with a Gender Perspective. Available at https://www.oas.org/en/CIM/docs/LabourCARICOM-Guide[EN].pdf [Accessed 15 April 2021].

Sen, Sankar, and P.M. Nair. 2005. A Report on Trafficking in Women and Children in India 20022003. New Delhi, India: Orient Longman.

Sharma, Nandita. 2005. «Anti-Trafficking Rhetoric and the Making of a Global Apartheid.» NWSA Journal, 17(3): 88-111. Available at muse.jhu.edu/article/189422 [Accessed 16 December 2017].

Tambe, Ashwini. 2009. Codes of Misconduct: Regulating Prostitution in Late Colonial Bombay. Minneapolis: University of Minnesota.

United Nations. 2000. Protocol to Prevent, Suppress and Punish Trafficking in Persons, Especially Women and Children, supplementing the United Nations Convention against Transnational Organized Crime. New York: UN. Available at https:/ / www. unodc.org/documents / treaties / Special/2000_Protocol_to_Prevent_2C_Suppress_ and_Punish_Trafficking_in_Persons.pdf [Accessed 18 August 2011].

Weeks, Jeffrey. 2011. The Languages of Sexuality. London, UK: Routledge.

Barnali Das. Assistant Professor at the Centre for Women's Studies, Dibrugarh University, Assam, India. She has written and taught in the field of gender-based violence. She has worked in a Ministry of Women and Child Development funded project in the Centre for Women's Studies, Dibrugarh University, titled «Stories Behind a Hot Cup of Assam Tea: Listening to the Voices of Women Labourers in the Tea Gardens». 
Rekha Pande is the Head of the Centre for Women's Studies and a Professor of History at the University of Hyderabad, India. She was the founding member of two Centers for Women's Studies in India. She was the Chair of the Women's World Congress in 2014. She has to her credit 20 books and 150 papers in national and international journals, proceedings and book chapters.

Received on 17 October 2020 and accepted for publication on 4 April 2021. 